\title{
Emergence of HBV resistance to lamivudine (3TC) in HIV/HBV co-infected patients in The Gambia, West Africa
}

\author{
Balint Stewart ${ }^{1}$, Modou L Jobarteh', Ramu Sarge-Njie ${ }^{1}$, Abraham Alabi ${ }^{1,2}$, Thushan de Silva ${ }^{1}$, Kevin Peterson ${ }^{1}$, \\ Ingrid Peterson ${ }^{1}$, Hilton Whittle ${ }^{1}$, Sarah Rowland-Jones ${ }^{1,3}$, Assan Jaye ${ }^{1}$, Matthew Cotten ${ }^{1,4}$ and Maimuna Mendy ${ }^{1,5^{*}}$
}

\begin{abstract}
Background: Lamivudine (3TC) is a potent inhibitor of both Hepatitis B virus (HBV) and Human Immunodeficiency Virus (HIV) replication and is part of first-line highly active antiretroviral therapy (HAART) in the Gambia. Unfortunately, the effectiveness of 3TC against HBV is limited by the emergence of resistant strains.

Aim: The aim of this retrospective study was to characterise 3TC-resistant mutations in HBV from co-infected patients receiving HAART, by generating HBV polymerase sequence data and viral loads from HBV genotype $\mathrm{E}$ infected patients, both at initiation and during a course of 3TC therapy.

Method: Samples from 21 HBV chronic carriers co-infected with HIV-1 $(n=18), \operatorname{HIV}-2(n=2)$ and HIV-dual $(n=1)$ receiving HAART for a period of 6-52 months were analysed for the emergence of 3TC-resistance mutations.

Findings: Sixteen out of $21 \mathrm{HBV} / \mathrm{HIV}$ co-infected patients responded well to HAART treatment maintaining suppression of HBV viraemia to low $\left(\leq 10^{4}\right.$ copies $\left./ \mathrm{mL}\right)(n=5)$ or undetectable levels $(<260$ copies $/ \mathrm{ml})(n=11)$. Out of the 5 non-responders, 3 had developed 3TC-resistant HBV strains showing mutations in the YMDD motif at

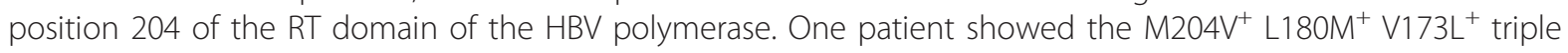
mutation associated with a vaccine escape phenotype, which could be of public health concern in a country with a national HBV vaccination programme. All except one patient was infected with HBV genotype E.

Conclusions: Our findings confirm the risk of 3TC mutations in HAART patients following monotherapy. This is a novel study on 3TC resistance in HBV genotype E patients and encourage the use of tenofovir (in association with 3TC), which has not shown unequivocally documented HBV resistance to date, as part of first-line therapy in HIV/ HBV co-infected patients in West Africa.

HBV- hepatitis B infection; HIV- human immunodeficiency virus; HAART- antiretroviral therapy.
\end{abstract}

\section{Background}

Hepatitis B virus (HBV) and human immunodeficiency virus (HIV) both pose significant public health challenges in the developing world. Globally, approximately $10 \%$ of HIV- infected individuals are also chronic carriers of HBV [1] as a consequence of shared modes of transmission. In The Gambia, where HBV is endemic the figure is closer to $15 \%$, with $\mathrm{HBV}$ infection

\footnotetext{
* Correspondence: maimunamendy@hotmail.com

${ }^{1}$ Medical Research Council, Fajara, P O Box 273, Banjul, The Gambia, West Africa

Full list of author information is available at the end of the article
}

occurring most commonly before the age of 4 years and usually preceding HIV infection [2,3].

Untreated HIV/HBV co-infection is characterised by higher HBV viral loads [4] and a reduction in the frequency of hepatitis B e antigen ( $\mathrm{HBeAg}$ ) seroconversion to antibody against $\mathrm{HBe}$ (anti-HBe), which is predictive of poorer clinical outcomes [5]. HIV/HBV co-infection is associated with higher liver-related morbidity and mortality compared to mono-infection with either virus [6]. With the increasing availability of highly active antiretroviral therapy (HAART) liver disease has become a leading cause of non-acquired immunodeficiency
() Biomed Central

C 2011 Mendy et al; licensee BioMed Central Ltd. This is an open access article distributed under the terms of the Creative Commons Attribution License (http://creativecommons.org/licenses/by/2.0), which permits unrestricted use, distribution, and reproduction in any medium, provided the original work is properly cited. 
syndrome (AIDS)- related death in $\mathrm{HIV} / \mathrm{HBV}$ coinfected patients [6].

In 1997 the Food and Drug Administration approved the use of 3TC, an orally-administered nucleoside analogue that potently suppresses replication of both HBV and HIV [7]. Based on WHO guidance, this drug is included in first-line HIV treatment in the Genito-Urinary Medicine (GUM) clinic in The Gambia; and is the only HBV-active drug routinely received by ART-naïve patients. Patient on 3TC monotherapy are at risk of developing resistant mutations following 1-2 years of treatment. Four major patterns of resistance mutations have been described. with the most important occurring in the highly conserved tyrosine-methionine-asparateaspartate (YMDD) motif, involving a change from methionine at position 204 in the reverse transcriptase domain (rt204) to either a valine or isoleucine residue (rtM204V/I) or, more rarely, a serine residue [8,9].

Compensatory mutations at other sites are usually required to reduce the loss in replication fitness associated with YMDD mutants [10,11]. As a result of significant open reading frame overlap in the HBV genome, changes in polymerase can lead to changes in the surface region which can induce changes in $\mathrm{HBsAg}$ secretion with significant reduction in HBsAg antigenicity [12-15].

As a result of the important role played by the secreted hepatitis B surface antigen (HBsAg) in immune recognition following vaccination, mutations in the $\mathrm{HBV}$ surface gene can have diagnostic and public health implications for universal vaccination programme.

The aims of this retrospective study was to, characterise $3 \mathrm{TC}$ resistance mutations in $\mathrm{HBV}$ genotype $\mathrm{E}$ chronic carriers receiving HAART.

\section{Results}

From an initial cohort of $31 \mathrm{HIV} / \mathrm{HBV}$ co-infected patients on HAART, 9 were excluded from the study either due to doubts about adherence to therapy $(\mathrm{n}=$ 2), seroreversion from serum HBsAg positive to HBsAg- negative during the recruitment period, prior to start of treatment $(n=1)$ or had been on treatment for $<6$ months $(\mathrm{n}=6)$. A $10^{\text {th }}$ patient was excluded because the patient's virus had the M204I mutation at the initiation of HAART and further investigation revealed that this patient had previously been on zidovudine AZT/3TC dual therapy when the mutation was likely to have emerged. The baseline characteristics of the remaining 21 patients are summarised in Table 1 . The patients were all adults, $(>$ 18 yrs old) and were co-infected with HIV-1 $(\mathrm{n}=18)$, HIV-2 ( $\mathrm{n}-2)$ or HIV-1 plus HIV-2 $(\mathrm{n}=1)$. Pre-treatment HBV viral loads ranged from undetectable levels $(<260$ copies $/ \mathrm{mL})$ to $1.0 \times 10^{9}$ copies $/ \mathrm{mL}$. Baseline
HBV viral load was high ( $\geq 10^{5}$ copies $/ \mathrm{mL}$ ) in the 6 HBeAg-positive patients and in 7/15 of the HBeAgnegative patients. Patients with high HBV DNA loads tended to have higher alanine aminotransferase and aspartate aminotransferase liver enzyme concentrations. The DNA sequence of all except one patient, were similar to HBV genotype $\mathrm{E}$.

\section{Response to therapy}

The median treatment duration was 25 (range 6 - 52) months. Patients were defined as responders to 3TC therapy if HBV viral loads were reduced to $\left(\leq 10^{4}\right.$ copies $/ \mathrm{ml}$ ) and if they showed sustained viraemic suppression throughout the period under study or as nonresponders if their viral load remained at high levels throughout the study or showed $>10^{4}$ copies $/ \mathrm{ml}$ at the end of the period of observation.

Sixteen (76.1\%) patients responded well to 3TC treatment, achieving sustained suppression of HBV viraemia; 11 of the $16(68.7 \%)$ patients had undetectable HBV DNA; $3(50 \%)$ of the HBeAg-positive individuals (Patients 10, 18 \&19) successfully seroconverted to HBeAg antibody positive and 1 of them (Patient 10) achieved loss of HBsAg as well. Two (66.6\%) of the 3 who had seroconverted to HBeAg antibody positive had viral load concentrations of $10^{4}$ or $10^{3}$ DNA copies per $\mathrm{mL}$ respectively.

The DNA sequences of 2 patients who did not respond to treatment and maintained HBV viral loads of $>10^{4}$ copies $/ \mathrm{mL}$ were similar to the wild-type sequence and not the 3TC-resistance mutations.

All, except 3 of the co-infected patients on HAART (\# $9,10 \& 28)$ achieved reduction in HIV viral load $(\leq 1.0$ $\times 10^{2}$ copies $/ \mathrm{mL}$ ) during the period of the study. Two of these patents were HBeAg positive at the start of therapy. Despite maintaining high levels of HIV RNA $\left(1.0 \times 10^{4}\right.$ copies $\left./ \mathrm{mL}\right)$, one of them (\#10) responded well to HBV treatment; achieving HBsAg clearance, and displaying $\mathrm{HBeAg}$ seroconversion and reduction in $\mathrm{HBV}$ viral load from $10^{8}$ copies $/ \mathrm{mL}$ to $10^{3}$ copies $/ \mathrm{mL}$ whilst the other patient (\#9) maintained high levels of both HIV RNA $\left(10^{4}\right.$ copies $\left./ \mathrm{mL}\right)$ and HBV DNA $\left(10^{9}\right.$ copies/ $\mathrm{mL})$.

\section{HBV-resistance mutations}

Alignment of the HBV RT sequences is shown in Figure 1. HBV resistance to 3TC was found in 3 of 21 (14.2\%) co-infected patients including the one patient (\#6) with HIV-dual infection who also tested positive for HBeAg (Tables 1 and 2). The remaining 2 patients with 3TCresistance mutations (\# 12 \& 13) were infected with a single HIV-1 strain. Patients with 3TC mutations had HBV viral load $\geq 10^{4}$ copies $/ \mathrm{mL}$ throughout the period of observation. 
Table 1 Baseline profiles and HBV/HIV viral load profile of 21 chronic HBV carriers on HAART

\begin{tabular}{|c|c|c|c|c|c|c|c|c|c|c|c|}
\hline \multicolumn{7}{|c|}{ Baseline time point } & \multicolumn{5}{|c|}{ Treatment } \\
\hline $\begin{array}{l}\text { Patient } \\
\text { ID }\end{array}$ & Age & Sex & $\mathrm{HBeAg}$ & $\begin{array}{l}\text { ALT/ } \\
\text { AST }\end{array}$ & $\begin{array}{l}\text { HIV } \\
\text { type }\end{array}$ & CD4 & $\begin{array}{l}\text { Treatment duration } \\
\text { (Months) }\end{array}$ & $\begin{array}{c}\text { HIV VL } \\
\text { Pre HAART }\end{array}$ & $\begin{array}{l}\text { HIV VL } \\
\text { end point }\end{array}$ & $\begin{array}{c}\text { HBV VL } \\
\text { Pre HAART }\end{array}$ & $\begin{array}{c}\text { HBV } \\
\text { VL } \\
\text { end } \\
\text { point }\end{array}$ \\
\hline & (yrs) & & & $\begin{array}{l}(\mathrm{IU} / \\
\mathrm{ml})\end{array}$ & & $\begin{array}{l}\text { Count } \\
\left(/ \mathrm{mm}^{3}\right)\end{array}$ & & $(\mathrm{c} / \mathrm{mL})$ & & $(\mathrm{c} / \mathrm{mL}$ & \\
\hline 1 & 42 & M & - & $33 / 28$ & HIV-1 & 110 & 25 & $1.0 \times 10^{6}$ & $1.0 \times 10^{2}$ & $6.5 \times 10^{4}$ & $\begin{array}{c}4.5 \times \\
10^{4}\end{array}$ \\
\hline 3 & 37 & $\mathrm{~F}$ & - & $32 / 23$ & HIV-1 & 10 & 25 & $8.7 \times 10^{5}$ & $1.0 \times 10^{2}$ & $2.8 \times 10^{4}$ & $<260$ \\
\hline 5 & 40 & M & - & $37 / 33$ & HIV-1 & 990 & 44 & $4.7 \times 10^{2}$ & $1.0 \times 10^{2}$ & $5.9 \times 10^{5}$ & $\begin{array}{c}2.4 \times \\
10^{8}\end{array}$ \\
\hline 6 & 35 & $\mathrm{~F}$ & + & $95 / 39$ & $\begin{array}{l}\mathrm{HIV}-1 \\
\& 2\end{array}$ & 300 & 33 & $\begin{array}{c}3.6 \times 10^{4}(\mathrm{HIV}-1)<1.0 \times \\
10^{2}(\mathrm{HIV}-2\end{array}$ & $\begin{array}{c}1.0 \times 10^{2} \\
(H I V-1 \& \\
H I V-2)\end{array}$ & $1.0 \times 10^{6}$ & $\begin{array}{c}3.7 \times \\
10^{7}\end{array}$ \\
\hline 7 & 28 & $\mathrm{~F}$ & + & $67 / 43$ & HIV-1 & 290 & 22 & $7.3 \times 10^{4}$ & $1.0 \times 10^{2}$ & $3.5 \times 10^{7}$ & $\begin{array}{c}1.4 \times \\
10^{3}\end{array}$ \\
\hline 9 & 44 & M & + & $83 / 25$ & HIV-1 & 240 & 6 & $2.3 \times 10^{8}$ & $1.0 \times 10^{2}$ & $5.4 \times 10^{8}$ & $\begin{array}{c}1.8 \times \\
10^{9}\end{array}$ \\
\hline 10 & 40 & M & + & $99 / 5$ & HIV-1 & 80 & 25 & $1.0 \times 10^{6}$ & $1.2 \times 10^{4}$ & $2.3 \times 10^{8}$ & $\begin{array}{c}6.5 \times \\
10^{3}\end{array}$ \\
\hline 12 & 48 & M & - & $38 / 21$ & HIV-1 & 80 & 26 & $1.0 \times 10^{6}$ & $2.0 \times 10^{4}$ & $3.0 \times 10^{7}$ & $\begin{array}{c}7.9 \times \\
10^{7}\end{array}$ \\
\hline 13 & 36 & M & - & $54 / 22$ & HIV-1 & 60 & 36 & $4.1 \times 10^{5}$ & $1.0 \times 10^{2}$ & $4.6 \times 10^{7}$ & $\begin{array}{c}2.5 \times \\
10^{7}\end{array}$ \\
\hline 16 & 41 & $\mathrm{~F}$ & - & $42 / 12$ & $\mathrm{HIV}-2$ & 340 & 25 & $1.3 \times 10^{6}$ & $1.0 \times 10^{2}$ & $1.2 \times 10^{8}$ & $<260$ \\
\hline 17 & 27 & M & - & NT & HIV-1 & 10 & 12 & $7.5 \times 10^{4}$ & $1.0 \times 10^{2}$ & $5.0 \times 10^{5}$ & $<260$ \\
\hline 18 & 50 & $\mathrm{~F}$ & + & NT & HIV-1 & 210 & 18 & $1.8 \times 10^{5}$ & $1.0 \times 10^{2}$ & $7.9 \times 10^{8}$ & $\begin{array}{c}8.1 \times \\
10^{4}\end{array}$ \\
\hline 19 & 24 & $\mathrm{~F}$ & + & $40 / 22$ & HIV-1 & 160 & 50 & $1.6 \times 10^{5}$ & $1.0 \times 10^{2}$ & $1.5 \times 10^{9}$ & $<260$ \\
\hline 21 & 42 & $\mathrm{~F}$ & - & $35 / 24$ & $\mathrm{HIV}-2$ & 650 & 24 & $1.5 \times 10^{4}$ & $1.0 \times 10^{2}$ & $1.7 \times 10^{4}$ & $<260$ \\
\hline 22 & 29 & $\mathrm{~F}$ & - & $42 / 21$ & HIV-1 & 160 & 24 & $1.0 \times 10^{6}$ & $1.0 \times 10^{2}$ & $1.1 \times 10^{9}$ & $\begin{array}{c}4.5 \times \\
10^{4}\end{array}$ \\
\hline 23 & 52 & M & - & $38 / 23$ & HIV-1 & 50 & 50 & $5.6 \times 10^{4}$ & $1.0 \times 10^{2}$ & $5.9 \times 10^{3}$ & $<260$ \\
\hline 24 & 29 & $\mathrm{~F}$ & - & $29 / 12$ & HIV-1 & 220 & 52 & $2.4 \times 10^{5}$ & $1.0 \times 10^{2}$ & $<260$ & $<260$ \\
\hline 25 & 31 & $\mathrm{~F}$ & - & $27 / 11$ & HIV-1 & 10 & 36 & $1.0 \times 10^{2}$ & $1.0 \times 10^{2}$ & $1.0 \times 10^{4}$ & $<260$ \\
\hline 26 & 50 & M & - & $32 / 19$ & HIV-1 & 130 & 30 & $3.0 \times 10^{5}$ & $1.0 \times 10^{2}$ & $9.2 \times 10^{3}$ & $<260$ \\
\hline 28 & 39 & $\mathrm{~F}$ & - & $21 / 4$ & HIV-1 & 360 & 19 & $4.2 \times 10^{3}$ & $1.4 \times 10^{3}$ & $2.8 \times 10^{4}$ & $<260$ \\
\hline 29 & 30 & $\mathrm{~F}$ & - & $\begin{array}{l}553 / \\
397\end{array}$ & HIV-1 & 220 & 36 & $5.1 \times 10^{5}$ & $1.0 \times 10^{2}$ & $5.7 \times 10^{8}$ & $<260$ \\
\hline
\end{tabular}

The upper normal limit of ALT and AST liver enzyme levels is 46 international units $/ \mathrm{ml}$ (IU/mL; NT-samples were not tested for AST and ALT.

The lower limit of detection of real-time PCR was 260 copies $/ \mathrm{mL}(\mathrm{c} / \mathrm{mL})$ and 100 copies $/ \mathrm{mL}$ for HBV and HIV respectively.

Figure 1 shows the amino acid sequence alignment of the HBV reverse transcriptase region surrounding the YMDD motif at the start of 3TC treatment and at the most recent time points. The M204V mutation was always accompanied by the mutation L180M. The virus from patient 12 had an S219A mutation, which reverted to the wild-type when 3TC resistance mutations V173L, L180M and M204V were acquired. Phylogenetic analysis of the HBV polymerase gene sequences showed close similarity with HBV genotype E, except in the case of 1 patient whose sequences were similar to HBV genotype A (data not shown).

\section{Discussion}

We retrospectively studied $21 \mathrm{HBV}$-HIV co-infected individuals on HAART to determine the patterns of 3TC resistance mutations. Apart from studies on the immune response to HAART treatment, we are not aware of any published studies on 3TC mutations from West Africa, a region where HBV genotype $\mathrm{E}$ infection predominates [16]. In our study, 11 out of 21 patients (52.3\%) displayed undetectable viral load at the last point of data collection. The remaining 5 patients had high viral load at the last observation point including 3 patients who had seroconverted to anti-HBe. $\mathrm{HBeAg}$ 


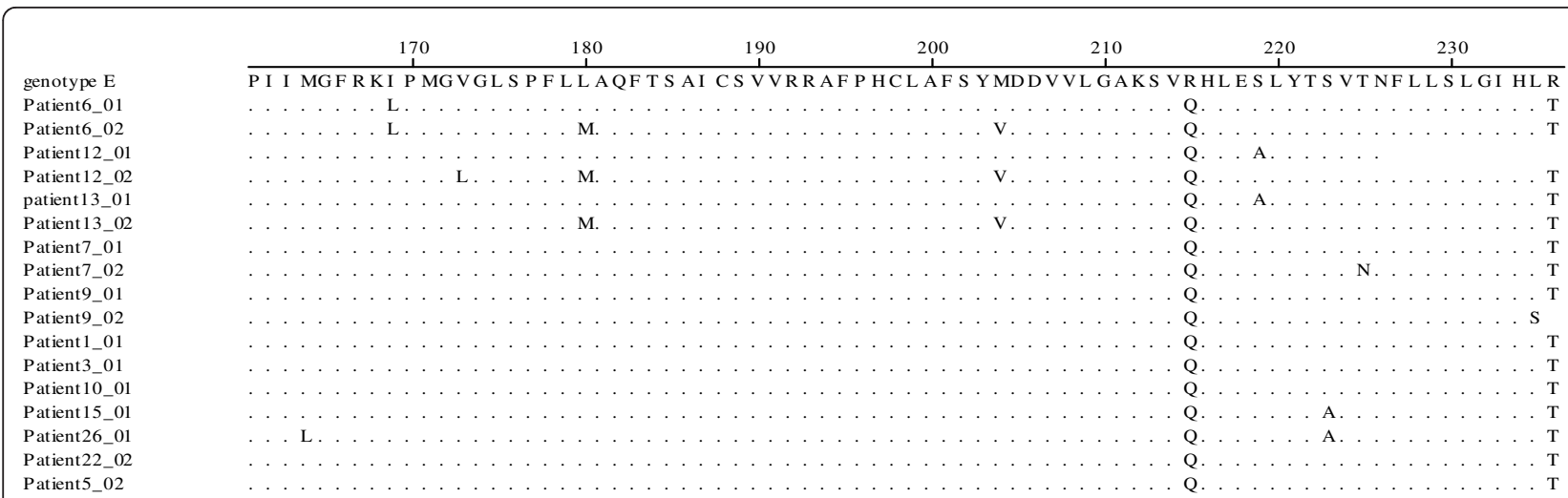

Figure 1 Amino acid sequence alignment generated from samples at baseline and at most recent time points covering amino acids 161 - 236 of the HBV reverse transcriptase domain. The HBV RT sequences are aligned with reference genotype E sequence (X75664) which is shown at the top, alignment with patient sequence is shown below with identities marked as (.) and sequence changes indicated by letter. Sequences from patients who developed YMDD mutations (patients 6, 12 and 13) during 3TC therapy are shown at the top half of the figure. The baseline and post treatment time points are represented by ' 01 ' and ' 02 ' respectively.

seroconversion usually confers a favourable outcome, however, HBV pre-core (PC) and basal core promoter (BCP) mutations should be excluded because of the clinical implications which could result from enhanced HBV replication or abrogation of HBeAg translation [17].

The observation of patient testing negative for HBsAg at the last point of observation should also be interpreted with caution, since the apparent loss of HBsAg may be due to a poor sensitivity and/or specificity of the assay in detecting mutation in the 'a' determinant region of HBsAg.

Because of the variation in the period of patient observation, it will be difficult to acurately define the rates of the events of $\mathrm{HBeAg}$ seroconversion or $\mathrm{HBsAg}$ clearance.

Despite its high efficacy, 3TC is not recommended for use as HBV monotherapy in HIV/HBV co-infected patients because of the risk of emergence of resistance mutations in HBV [18]. Similarly, the European AIDS Clinical Society guidelines for treatment of HBV/HIV co-infected patients recommend that patients with no indication of anti-HIV treatment should not be treated with drugs such as 3TC, entacavir and tenofovir because of the risk of developing HIV-resistant mutations [19]. However, the criteria for treatment for the patients in the study were based solely on their HIV status.
Although HIV-1 and HIV-2 infections currently show similar prevalence in The Gambia, patients infected with HIV-2 are far less likely to progress to AIDS than patients infected with HIV-1 [20]; thus when considering all HIV-1 and HIV-2 patients on HAART, there is a bias towards HIV-1 infections.

The introduction of 3TC-containing HAART is a relatively recent development in The Gambia, and therefore, 3TC-resistance mutations were not observed in therapynaïve individuals in the present study. However, with the continued use of 3TC as the only HBV-active drug in HAART patients, the proportion of resistant strains may increase with time, which will significantly reduce HBV treatment effectiveness [21].

Thus due to the potential association of the triple 3TC mutations $\left(\mathrm{M} 204 \mathrm{~V}^{+} \mathrm{L}_{180 \mathrm{M}^{+}} \mathrm{V}_{173 \mathrm{~L}^{+}}\right)$with vaccine escape mutants, the continuous surveillance of resistance mutants is necessary in a country with a national HBV vaccination programme [22,23]. Additionally, with the decline in HIV-associated morbidity and mortality following the introduction of HAART, there is a need for screening of HIV patients for underlying viral hepatitis co-infection and the provision of management and treatment recommendations for patients with chronic viral hepatitis in preventing the development of liver disease.

Table 2 Patterns of mutation found in patients who developed YMDD 3TC resistant mutants

\begin{tabular}{lccl}
\hline Patient ID & & 3TC Mutations & Time after initiation of LMV therapy (months) \\
\hline Patient 6 & M204V & L180M & 25 \\
Patient 12 & M204V & L180M & V173L* \\
Patient 13 & M204V & L180M & 16 \\
\hline
\end{tabular}

Times given for when mutation occurred correspond to the first sample given during therapy in which resistance mutations were detected.

*V173L mutation occurred after 23 months from initiation of therapy. 


\section{Materials and methods Subjects}

Five hundred and seventy HIV-positive individuals were screened for hepatitis B markers. Seventy (12.2\%) of them were $\mathrm{HBsAg}$-positive and 31 were receiving HAART that included 3TC (300 mg/day). Samples from 21 out of the 31 co-infected patients receiving HAART were analysed retrospectively. Six (28.5\%) of the 21 patients tested positive for HBeAg, 18 (85.7\%) for HIV1, 2 (9.5\%) for HIV-2 and 1 for HIV-dual infections. The HIV viral load ranged from undetectable to $1.1 \times 10^{9}$ (Table 2).

Seventeen of these patients had received 3TC in combination with another reverse transcriptase inhibitor (NRTI) usually AZT or Stavudine, and a non-nucleoside reverse transcriptase inhibitor, nevirapine or efavirenz. The four remaining patients received a combination of AZT, 3TC and lopinavir/ritonavir (LPV/r), either due to HIV-2 or HIV-1/2 dual infection, or previous exposure to single dose nevirapine. Two individuals moved onto second-line HIV-1 therapy of Tenofovir (TDF), an NRTI dually active against HBV and HIV, in combination with AZT, 3TC and LPV/r following non-suppression of HIV viraemia by first-line therapy. Patients were excluded from the study if there were any doubts as to their compliance to therapy (critical in the effectiveness of 3TC) [21]. Ethical approval was granted by the joint Gambia Government/MRC Ethics Committee. All subjects and/or legal guardians provided written, informed consent.

\section{Serological assays}

Detection of HBsAg was performed using Determine ${ }^{\mathrm{TM}} \mathrm{HBs} A g$ immunochromatographic test (Abbott Laboratories, USA). Samples were also tested for $\mathrm{HBeAg}$ and anti-HBe using an ELISA assay (DiaSorin, Salugia, Italy).

CD4 T-cell count and HIV-1/HIV-2 viral load determination Absolute CD4 T cell counts as well as CD4 lymphocyte proportions were determined by flow cytometry (Becton-Dickinson, Belgium) and plasma HIV-1 and HIV-2 viral load measurements made using an in-house quantitative PCR (qPCR) methodology as described previously [24].

\section{Biochemical assays}

Liver function tests were performed using Vitros DT60 II Chemistry analyzer (Ortho-Clinical Diagnostics, Bucks, UK) according to manufacturer's instructions.

\section{Determination of HBV viral loads by real-time qPCR}

Measurement of HBV viral load was performed using an in-house SYBR-Green method according to a previously described protocol [25], with primers HBV Taq 1 and HBV Taq 2 (Table 3). The limit of detection for the assay was 260 copies $/ \mathrm{mL}$ and samples with viral loads higher than the top of the standard curve were diluted 1:1000 and retested.

\section{Amplification and sequencing of YMDD region of HBV polymerase gene}

Primers for polymerase amplification were designed on the basis of conserved regions both flanking and within the reverse transcriptase region of the HBV polymerase gene, using a consensus sequence generated from reference sequences of genotypes $\mathrm{E}$ and $\mathrm{A}$, as these are the most commonly encountered HBV genotypes in The Gambia $[26,27]$. The primers were synthesized by Metabion International AG (Planegg, Germany) and subsequently diluted to a concentration of $10 \mu \mathrm{M}$ for use, according to manufacturer's instructions (Table 3).

Twenty microliters of serum was diluted 1:10 in nuclease-free water and HBV DNA extracted using the QIAamp DNA Mini Kit (Qiagen, Crawley, West Sussex, UK) and then re-suspended in $100 \mu \mathrm{L}$ water. The 50-uL PCR reaction mix contained $5 \mu \mathrm{L}$ of purified HBV DNA $25 \mu \mathrm{L}$ HotStar Taq Master Kit (Qiagen) and $2.0 \mathrm{uL}$ each of MMHBRT5 and MM HBRT6 primers. The PCR thermocycler conditions were optimised with an initial incubation at $95^{\circ} \mathrm{C}(15 \mathrm{mins}), 40$ cycles at $94^{\circ} \mathrm{C}(30 \mathrm{~s})$ for denaturation, $52^{\circ} \mathrm{C}(30 \mathrm{~s})$ annealing followed by extension at $72^{\circ} \mathrm{C}(1 \mathrm{~min})$ which resulted in the amplification of 577-bp length of the reverse transcriptase domain covering the YMDD region. PCR products were then cleaned using the QIAquick ${ }^{\circledR}$ agarose gel extraction kit (Qiagen) and sent to Macrogen, Korea for direct single-extension sequencing using the same primers (MMHBRT5 and MMHBRT6) and $3730 \times 1$ DNA analyzer (PE Applied Biosystems, Warrington, UK).

Table 3 Primers designed for amplification and sequencing of HBV reverse transcriptase domain

\begin{tabular}{|c|c|c|c|c|c|}
\hline Primer ID & Nucleotide sequences & & Product size (bp) & & Nucleotide positions \\
\hline HBV TAQ 1 & 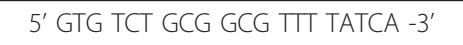 & Sense & 97 & DNA quantification & $379-398$ \\
\hline HBV TAQ 2 & 5' GAC AAA CGG GCA ACA TAC CTT-3' & Antisense & & & $476-456$ \\
\hline MM HBRT5 & $5^{\prime}-$ ATCCTGCTGCTATGCCT - 3' & Sense & 576 & polymerase Amplification & $410-426$ \\
\hline MM HBRT6 & $5^{\prime}-$ ACTTCCAATCAATAGGCC - 3' & Antisense & & & $986-968$ \\
\hline
\end{tabular}




\section{Data management}

DNA sequences were edited and assembled using SeqMan and aligned using MegAlign Lasergene software (DNAstar, Madison, WI, USA) with reference sequences of genotype E and A [accession numbers X75664 (Kou) and AM410963 respectively].

\section{Acknowledgements}

We are indebted to the participants who provided the blood samples. We would like to thank Adam Jeng, Alasana Bah, Bankole Ahadzie, Professor Richard Tedder and Samreen ljaz, Steve Kaye, Irfan Zaidi, Saihou Sabally, Toyin Togun, Ayesha Akinkugbe, Christopher Akolo, Tahir Mohammed, Francis Oko, Uduak Okomo, Maarten Schim van der Loeff, Marianne van der Sande, and Samuel McConkey, Ken Joof and the GUM clinic staff, for their assistance.

We extend our gratitude to the Medical Research Council (Fajara) and UN Global Fund for providing the financial support and funding for ARV.

\section{Author details}

'Medical Research Council, Fajara, P O Box 273, Banjul, The Gambia, West Africa. ${ }^{2}$ Medical Research Unit, Albert Schweitzer Hospital, Lambarene, Gabon. ${ }^{3}$ Weatherall Institute of Molecular Medicine, University of Oxford, John Radcliffe Hospital, Headington, Oxford OX3 9DS, UK. ${ }^{4}$ Wellcome Trust Sanger Institute, Hinxton, Cambridge CB10 1SA, UK. ${ }^{5}$ International Agency For Research on Cancer (IARC), 150 Cours Albert Thomas, Lyon 69372, France.

\section{Authors' contributions}

Study concept and design: MM, BS, MLJ; Data analysis: IP, BS, MM. contribution to assembling of the longitudinal HIV cohort: HW, AJ, RSN, AA, SRJ, KP; responsibility for patient recruitment and treatment: TDS, KP; contributed to the drafting the manuscript: BS, MM, IP, MC, HW, TDS; and writing the paper: BS and MM. All authors read and approved the final version of the manuscript.

\section{Competing interests}

The authors declare that they have no competing interests.

Received: 10 March 2011 Accepted: 23 December 2011 Published: 23 December 2011

\section{References}

1. Soriano $V$, Barreiro $P$, Nunez $M$ : Management of chronic hepatitis $B$ and $C$ in HIV-coinfected patients. J Antimicrob Chemother 2006, 57:815-818.

2. Jobarteh M, Malfroy M, Peterson I, Jeng A, Sarge-Njie R, Alabi A, et al: Seroprevalence of hepatitis B and C virus in HIV-1 and HIV-2 infected Gambians. Virol J 2010, 7:230.

3. Whittle HC, Bradley AK, McLauchlan K, Ajdukiewicz AB, Howard CR, Zuckerman AJ, et al: Hepatitis B virus infection in two Gambian villages. Lancet 1983, 1:1203-1206.

4. Levy V, Grant RM: Antiretroviral therapy for hepatitis B virus-HIVcoinfected patients: promises and pitfalls. Clin Infect Dis 2006, 43:904-910.

5. de Jongh FE, Janssen HL, de Man RA, Hop WC, Schalm SW, van Blankenstein M: Survival and prognostic indicators in hepatitis B surface antigen-positive cirrhosis of the liver. Gastroenterology 1992, 103:1630-1635.

6. Thio CL, Seaberg EC, Skolasky R Jr, Phair J, Visscher B, Munoz A, et al: HIV-1, hepatitis B virus, and risk of liver-related mortality in the Multicenter Cohort Study (MACS). Lancet 2002, 360:1921-1926.

7. Chang CN, Skalski V, Zhou JH, Cheng YC: Biochemical pharmacology of (+)- and (-)-2',3'-dideoxy-3'-thiacytidine as anti-hepatitis B virus agents. J Biol Chem 1992, 267:22414-22420.

8. Westland CE, Yang H, Delaney WE, Wulfsohn M, Lama N, Gibbs CS, et al: Activity of adefovir dipivoxil against all patterns of lamivudine-resistant hepatitis B viruses in patients. J Viral Hepat 2005, 12:67-73.

9. Bozdayi AM, Uzunalimoglu O, Turkyilmaz AR, Aslan N, Sezgin O, Sahin T, et al: YSDD: a novel mutation in HBV DNA polymerase confers clinical resistance to lamivudine. J Viral Hepat 2003, 10:256-265.
10. Melegari M, Scaglioni PP, Wands JR: Hepatitis B virus mutants associated with 3TC and famciclovir administration are replication defective. Hepatology 1998, 27:628-633.

11. Ono SK, Kato N, Shiratori Y, Kato J, Goto T, Schinazi RF, et al: The polymerase L528M mutation cooperates with nucleotide binding-site mutations, increasing hepatitis B virus replication and drug resistance. J Clin Invest 2001, 107:449-455.

12. Araujo NM, Branco-Vieira M, Silva AC, Pilotto JH, Grinsztejn B, de Almeida AJ, et al: Occult hepatitis B virus infection in HIV-infected patients: Evaluation of biochemical, virological and molecular parameters. Hepatol Res 2008, 38:1194-1203.

13. Honkoop P, de Man RA, Niesters HG, Zondervan PE, Schalm SW: Acute exacerbation of chronic hepatitis B virus infection after withdrawal of lamivudine therapy. Hepatology 2000, 32:635-639.

14. Kamili S, Sozzi V, Thompson G, Campbell K, Walker CM, Locarnini S, et al: Efficacy of hepatitis B vaccine against antiviral drug-resistant hepatitis B virus mutants in the chimpanzee model. Hepatology 2009, 49:1483-1491.

15. Sheldon J, Ramos B, Garcia-Samaniego J, Rios P, Bartholomeusz A, Romero $\mathrm{M}$, et al: Selection of hepatitis B virus (HBV) vaccine escape mutants in HBV-infected and HBV/HIV-coinfected patients failing antiretroviral drugs with anti-HBV activity. J Acquir Immune Defic Syndr 2007, 46:279-282.

16. Idoko J, Meloni S, Muazu M, Nimzing L, Badung B, Hawkins C, et al: Impact of hepatitis $B$ virus infection on human immunodeficiency virus response to antiretroviral therapy in Nigeria. Clin Infect Dis 2009, 49:1268-1273.

17. Chu CM, Liaw YF: Chronic hepatitis B virus infection acquired in childhood: special emphasis on prognostic and therapeutic implication of delayed HBeAg seroconversion. J Viral Hepat 2007, 14:147-152.

18. Iser DM, Sasadeusz JJ: Current treatment of HIV/hepatitis B virus coinfection. J Gastroenterol Hepatol 2008, 23:699-706.

19. Rockstroh JK, Bhagani S, Benhamou Y, Bruno R, Mauss S, Peters L, et al: European AIDS Clinical Society (EACS) guidelines for the clinical management and treatment of chronic hepatitis $B$ and $C$ coinfection in HIV-infected adults. HIV Med 2008, 9:82-88.

20. de Silva TI, Cotten M, Rowland-Jones SL: HIV-2: the forgotten AIDS virus. Trends Microbiol 2008, 16:588-595.

21. Selabe SG, Lukhwareni A, Song E, Leeuw YG, Burnett RJ, Mphahlele MJ: Mutations associated with lamivudine-resistance in therapy-naive hepatitis B virus (HBV) infected patients with and without HIV coinfection: implications for antiretroviral therapy in HBV and HIV coinfected South African patients. J Med Virol 2007, 79:1650-1654.

22. Lacombe K, Gozlan J, Boelle PY, Serfaty L, Zoulim F, Valleron AJ, et al: Longterm hepatitis B virus dynamics in HIV-hepatitis B virus-co-infected patients treated with tenofovir disoproxil fumarate. AIDS 2005, 19:907-915.

23. Viviani $S$, Jack A, Hall AJ, Maine N, Mendy M, Montesano R, et al: Hepatitis B vaccination in infancy in The Gambia: protection against carriage at 9 years of age. Vaccine 1999, 17:2946-2950.

24. Jallow S, Alabi A, Sarge-Njie R, Peterson K, Whittle H, Corrah T, et al: Virological response to highly active antiretroviral therapy in patients infected with human immunodeficiency virus type 2 (HIV-2) and in patients dually infected with HIV-1 and HIV-2 in the Gambia and emergence of drug-resistant variants. J Clin Microbiol 2009, 47:2200-2208.

25. Mendy ME, Kaye S, Van der Sande M, Rayco-Solon P, Waight PA, Shipton D, et al: Application of real-time PCR to quantify hepatitis B virus DNA in chronic carriers in The Gambia. Virol J 2006, 3:23.

26. Dumpis U, Mendy M, Hill A, Thursz M, Hall A, Whittle H, et al: Prevalence of HBV core promoter/precore/core mutations in Gambian chronic carriers. J Med Virol 2001, 65:664-670.

27. Mendy ME, McConkey SJ, Sande van der MA, Crozier S, Kaye S, Jeffries D, et al: Changes in viral load and HBsAg and HBeAg status with age in HBV chronic carriers in The Gambia. Virol J 2008, 5:49.

doi:10.1186/1756-0500-4-561

Cite this article as: Stewart et al:: Emergence of HBV resistance to lamivudine (3TC) in HIV/HBV co-infected patients in The Gambia, West Africa. BMC Research Notes 2011 4:561. 